COMMENT

DOI: $10.1057 /$ s41599-017-0048-6

\title{
The rise of the quasi-public space and its consequences for cities and culture
}

Andy $\operatorname{Pratt}^{1}$

ABSTRACT This article argues that whilst appearing new, quasi-public spaces have emerged from a process of investment restructuring over the last 50 years. The profound change that is set in motion is a loss of control of public space and its cultural uses in cities. The tensions set up in this transformation are illustrated by the cultural fortunes of the largest such space in London, Granary Square; and, that of the City of London that has little, if any, public space. 


\section{The rise of quasi-public spaces and urban culture}

new phenomenon is emerging in London: quasi-public spaces. These are open spaces that look and feel like public places, open to all; however, they are in fact private spaces that are only conditionally made available to the public. Hence, the other common usage coined with respect to New York: 'Privately owned public space' (Kayden, 2000). This paper argues that whilst appearing new, quasi-public spaces have emerged from a process of investment restructuring over the last 50 years. The profound change that is set in motion is a loss of control of public space and its cultural uses in cities.

There is a long history to the notion of providing public spaces in cities, often linked to the notion of the agora, symbolising democratic processes (Sennet, 1999). Furthermore, public spaces have commonly been a means of the local state (often supported by a local mercantile group seeking cultural and political legitimacy) articulating the 'civilising' values of culture. Commonly such sites have been developed as part of a grand civic vision associated with libraries, galleries and museums, as well as the signifiers of democracy such as town halls, and public open spaces. In the UK the mid/late-18th century gave us examples in Leeds, Birmingham and Manchester to mention a few.

There has been an accompanying debate about land use in cities: one strand arguing that ownership, regulation and planning have eroded access for particular groups, and in so doing have restricted the 'right to the city' to privileged groups; another strand, argues more about the restriction of access to public spaces via physical barrier, police or surveillance that impedes the possibility of assembling crowds in public expressions of political dissent (Mitchell, 2003).

The new quasi-public spaces are a subtle hybrid, which offer deceptive access that can be revoked at any time. However, in the short-term developers have invested significant sums in such sites, with landscaping and design of a high quality; moreover, as reported here, some have also programmed cultural events (in fact providing what cash-strapped local authorities cannot; Pratt, 2017a). When proposed and developed these sites are seen as enabling, and cost-saving, for public authorities; many promises are made regarding access: but, these are often legally weak, or malleable. This is the nub of the problem: public open spaces are being passed over to private control, and public cultural provision is defaulting to the private sector. In the context of the severe financial cut backs to cultural departments this outcome might seem positive. However, it disregards the fact that in the longerterm developers, who commonly see such developments as a lossleader in long-term project development; as the site reaches full letting, the 'public space' is under threat. Moreover, the programming of the site is always going to be in the interest of the land owners or investors, they are not accountable to the taxpayers and general population and to represent a wider cultural diversity.

This paper is illustrated by the case of Granary Square, located directly north of the Kings Cross/St Pancras main rail stations in North central London, a former goods yard, a site that has been 'in development' for twenty years or so, but is now rapidly being built out. In this sense, it is the latest iteration of the 'quasi-public space'. In the 20th Century the development of new towns, especially the second phase in the 1960s gifted cities a modernist version of the agora, linked to new civic spaces, which were characterised by retailing. I want to argue that such a further shift took place subsequently, which is the precursor of the current quasi-public space.

\section{Quasi-public space: retail and industrial gentrification}

In response to both the suburban residential trends of cities, and de-industrialisation, retailing has undergone a massive transformation signalled by the out of town shopping centre, and 'hyper'-market development. In turn, this has impacted upon traditional urban cores, which have been put in competition for retailers (Guy et al., 2002). The first step left a significant mark on provincial city centres, the development of in-town covered shopping centres. What is significant for the current argument is the fact that in effect inner city shopping streets were 'enclosed'. What appears to be a convenience against inclement weather and in favour of transport flow also led to the whole scale ownership of large prime urban space by private investors, and shopping centre operators. These third-party operators then took on 'policing' via private security guards, who could eject 'undesirables' for simply loitering: shopping centres are not public spaces. Interestingly, the dominant new owners of these new centres were insurance companies and pension funds. Ironically, the endowner of this new quasi-public space is the public; however, it is an atomised and unorganised public compared to the previous state ownership. Access rights and use is now linked auditors' concerns to the increase pension earnings of investors; but not to the wider well-being the state and society.

The second phase of de-industrialisation has been the largescale transformation of derelict inner-city industrial spaces. Here, just as in the case of housing, the shift to private development has displaced public development and ownership. The resulting forprofit schemes which are also, in the end, financed by pension funds other major investors inevitably favour higher land values and force out those who either have no stake, or minimal income. Housing regeneration does not necessarily mean gentrification, it can me improvement. As with housing, and retail, the transformation of industrial space is being financialised. The victims are users of industrial space (commonly either micro enterprises, cultural or art workers), who are forced out in redevelopment either by premium office or residential users thus completing a cycle of recalibrating the 'right to the city' another notch (Pratt, 2017b).

Herein we can see another dilemma: cities seeking to chase the 'creative city' dream have sought to attract high-tech companies with the patina of a rough edge of art and creativity; however, the normative Flordia (2002) model, is focused on the consumption desires of the 'high tech millennial'-as has been shown many times this process simply drives our artists as land values increase. In the end, the creative city is a hollow shell unless it sustains and supports creative workers.

\section{Granary square, London: the new public space}

The largest, and arguably most successful, urban regeneration project in London in recent years that has decisively created a sense of place, as well as a cultural and innovative fission is Granary Square (Moore, 2014). Granary Square is the most apparent manifestation of the redevelopment of the swathes of disused goods marshalling yards behind King's Cross and St Pancras railway stations. The site, extending way beyond Granary Square, has been mired in planning enquiries and public contestation over the lack of public housing in the plan (Edwards, 2009). Granary Square is the largest new public space in London, with dancing fountains, surrounded by street level restaurants and food trucks, and backing onto the major building that houses world renowned Central St Martins School of Art. Google is due to begin building its London HQ on the opposite side of the square. This seems like an artful confection of the Richard Flordia (2002) style 'Creative City': indeed, it is, in the sense that such developments are socially and economically divisive pandering disproportionately to the desires of the 'creative class'.

One would have expected that the local authority, Camden, would be the progenitor of such a development. In fact, this 
development is private, and the 'public' space is private too. The developer has worked on behalf of the owners (Australian Super) in promoting access and public cultural programming; far in excess of the total annual cultural budget of Camden. ${ }^{1}$ Is this then a neo-liberal success? The answer is conditional, as the developers can, and will, revert to the normal rules of property ownership and access as, and when, it suits them. In the meantime, the public does gain much from this development. This is just as well, because the cultural budget of Camden, like most other local authorities under the imposition of austerity, has been slashed to close on zero. However, it is the long-term consequences for sites such as this, culture and the city that we need to highlight.

\section{The culture mile: the lack of public space}

We can perhaps see the logical end-point of this type of development, and some negative consequences, especially for the cultural sector. A couple of miles south of Kings Cross lies the City of London, nominally a 'local authority', but in fact the City of London has power and resources beyond the normal local authority backed by the power of the medieval (but modern investors) Guilds. The City of London and Culture have always had a particular relationship; an elite idealism, and the reductive 'value for money' attitude that lies at the back of many local authorities, finds full voice from the financial community and the City of London. In a sense, with such a small resident population one might expect little of the City, aside from a sprinkling of elite arts venues. The City is certainly not a cultural hot spot, nor one that appeals to a wide audience, and neither has it aspired to be so until recently.

The City's cultural backbone is the Barbican: this development occupies a former Second World War bomb-damaged site in a prime position; the development is a classic sixties style (neomodernist) with a large public space at its core (although turned away from the neighbouring streets). It seeks to create a public agora with the City of finance. The City of London has woken up to the potential role that culture can play in innovation, inclusion and transformation. The City has recently launched a cultural hub branded the 'The Culture Mile'. It has teamed The Barbican, The museum of London, The Guildhall School of Music, and the London Symphony Orchestra (who are planning to build a new concert hall for their conductor, Sir Simon Rattle) as part of London Cross-Rail redevelopment. The challenge that the City faces is that people do not want to go there (unless it's to work), and it lacks a cultural buzz. By default, the City in effect has rejected the role of public space in favour of 'productive' real estate, the streets are empty of cultural life as workers hurry from A to B. It was instructive that during the Occupy London protesters (2011-12) could find nowhere to 'occupy' that was public space: Paternoster Square in front of the London Stock Exchange is another quasi-public space (owned by the Mitsubishi Estate Company). Ironically, the space that was eventually the site of the encampment was outside St Paul's on church land, traditional sanctuary; although, in the end they were evicted from this site too.

The initiative of the 'Culture mile' aspires not just to brand but to create a public space for culture. In its absence, the institutions have had to pursue a strategy of opening 'quasi-private space'; they have sought to open up their foyer and internal circulation spaces to be an internal agora; to bring the street inside: illustrating the presence of an absence of public space. In effect, The Culture Mile is the other side of the paradoxical coin from Granary Square. Nominally public, unable thus far to develop a public realm, and forced to internalise it; whereas at King's Cross a private body owns an apparent an 'public realm'.

\section{Losing control of public space in cities}

By framing quasi-public spaces in the longer-term process of financializing land and property in cities we can see how it has 'crept up on us'. What is of particular concern has been the seeming lack of response from policy makers to counter the consequential impacts on cultural diversity and gentrification.

Public space is a critical component of how we have traditionally understood 'the city'; especially its civic and cultural virtues, which were presented as a counterbalance to uncontrolled acquisitive behaviour. However, the nature of public space is being challenged. Fundamentally, cities are in danger not simply of taking the wrong policy direction, but of literally losing control of the public realm and a crucial opportunity to shape public culture. Today, culture is often an instrumental hook to 'place branding' and attracting foreign direct investment. Understood in this way, consumer culture, and retail consumption (or increasingly the experience of shopping) is the end point. However, irreducibly this must mean that the market is for the richest and most privileged, it is not profitable to promote the cultural diversity that would appeal to the whole community, non-elite shopping experiences, or non-'high' culture venues. Diversity in style, in culture, in income and experience is what the city stands to lose.

Public spaces have, as noted, always carried a democratic symbolism. However, the non-economic exchange of ideas and knowledge that is increasingly becoming an important part of 'open innovation' rely upon a 'rich mix' of ideas, cultures and people. Just as the 'big science' style of innovation based upon secrecy and closure has suffered, we need more than ever the possibilities offered by open and public spaces. As we have seen in the traditional cultural realm the 'public' has to be created 'in spite of the city'. We can also point to the inevitable privatised agora of many creative organisations that have constructed privatised public spaces within their building or campus.

Received: 24 July 2017 Accepted: 15 November 2017

Published online: 28 November 2017

\section{Note}

1 The UK Government sale of $£ 371 \mathrm{~m}$ of the 63 -acre site in 2016 was promoted as a critical part of bringing the UK deficit down.

\section{References}

Edwards M (2009) King's Cross: renaissance for whom? In: PUNTER J (ed) Urban design, urban renaissance and British cities. Routledge, London

Flordia RL (2002) The rise of the creative class: and how it's transforming work, leisure, community and everyday life. Basic Books, New York, NY

Guy S, Henneberry J, Rowley S (2002) Development cultures and urban regeneration. Urban Stud 39(7):1181-1196

Kayden JS (2000) Privately owned public space: the New York city experience. John Wiley \& Sons, London

Mitchell D (2003) The right to the city: social justice and the fight for public space. Guilford Press, Lodnon

Moore R (2014) All hail the new King's Cross-but can other developers repeat the trick? The Guardian

Pratt A (2017a) Beyond resilience: learning from the cultural economy. Eur Plan Stud 25(1):127-139

Pratt AC (2017b) Gentrification, artists and the cultural economy. In: Lees L, Philips M (eds) Handbook of gentrification studies. Edward Elgar, Cheltenham

Sennet R (1999) The spaces of democracy. In: Beauregard R, Body-Gendrot S (eds) The urban moment. Cosmopolitan essays on the late 20th century city. Sage, London

\section{Additional information}

Competing interests: The author declares no competing financial interests. 
Reprints and permission information is available online at http://www.nature.com/ reprints

Publisher's note: Springer Nature remains neutral with regard to jurisdictional claims in published maps and institutional affiliations.

\section{(c) (i)}

Open Access This article is licensed under a Creative Commons Attribution 4.0 International License, which permits use, sharing, adaptation, distribution and reproduction in any medium or format, as long as you give appropriate credit to the original author(s) and the source, provide a link to the Creative
Commons license, and indicate if changes were made. The images or other third party material in this article are included in the article's Creative Commons license, unless indicated otherwise in a credit line to the material. If material is not included in the article's Creative Commons license and your intended use is not permitted by statutory regulation or exceeds the permitted use, you will need to obtain permission directly from the copyright holder. To view a copy of this license, visit http://creativecommons.org/ licenses/by/4.0/.

() The Author(s) 2017 